\title{
Measuring the Efficiency of Tertiary Care Hospitals and Medical Colleges in Punjab, an Application of Non- Parametric Approach DEA
}
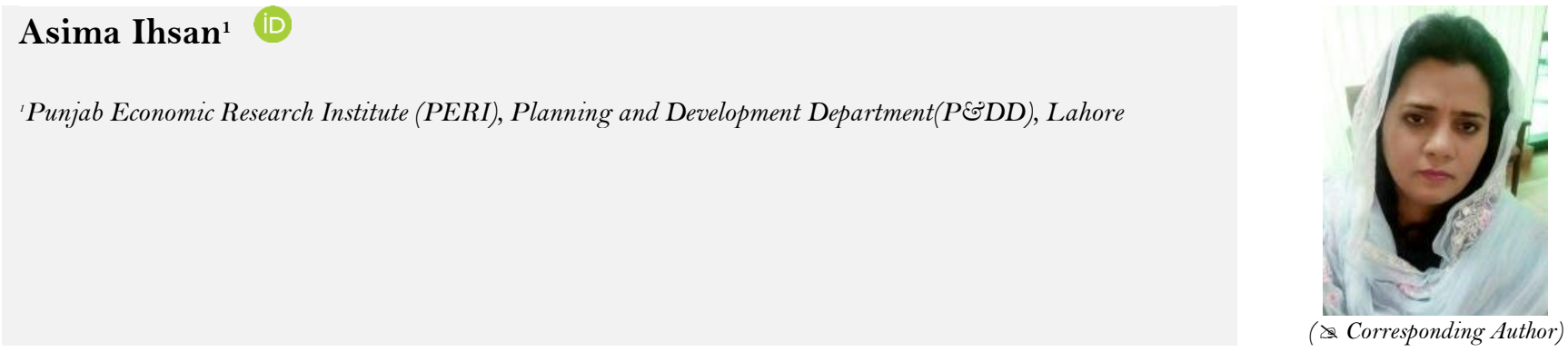

\begin{abstract}
Efficient utilization of resources required that the healthcare units should operate at their full capacity and increase their efficiency to yields best quality healthcare services and more savings. To measure the capacity utilization of medical collages/attached teaching hospitals in Punjab, the study incorporated the Data Envelopment Analysis (DEA). This is a cross sectional study for the academic year 2015, by using the primary data collected by "Punjab Economic Research Institute (PERI “. The main objective to address the efficiency issue in this study is to provide empirical evidence for public policy to provide for tertiary health care facilities. The results showed that $78 \%$ medical colleges in a sample data are unity, indicating that they are perfectly utilizing their resources while the remaining $22 \%$ have more close to unity, showing that they have only small capacity to increase their output within available resources. In case of teaching hospitals, there are $56 \%$ hospitals in Punjab, which are not operating at their maximum level of output indicating that they have the capacity to provide more services. While $44 \%$ are using their resources efficiently. The higher efficiency score of medical colleges/teaching hospital in provincial capital reflected the fact that Decision Making Units (DMUs) in Lahore are relatively more efficient in the management of resources. In the second stage, by using a Tobit regression, the inefficacies are regressed against various indicators of inputs and outputs. Finally, the finding of this study suggests some policy recommendation to make the medical colleges/teaching hospitals more resource effective in order to accelerate the highest efficiency scores.
\end{abstract}

Keywords: Data development analysis, Medical colleges efficiency, Hospitals efficiency, Tobit regression.

\section{Contents}

1. Introduction

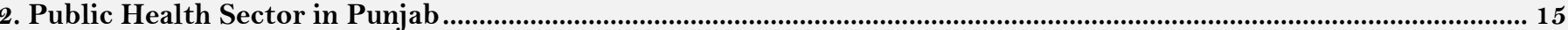

3. Private and Public-Sector Tertiary Care Hospitals in Punjab ................................................................................................ 17

4. Objective of the Study ................................................................................................................................................... 17

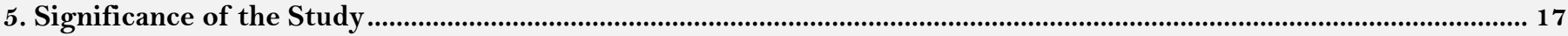

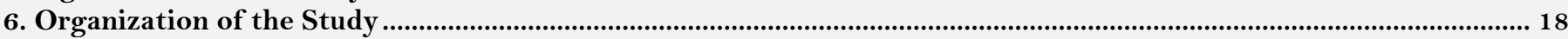

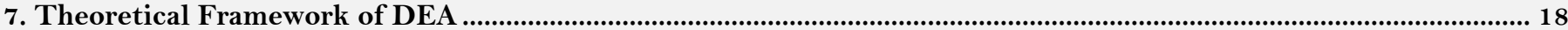

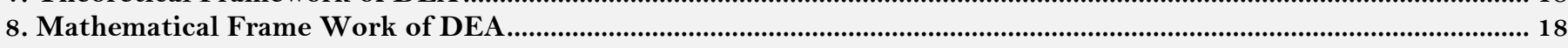

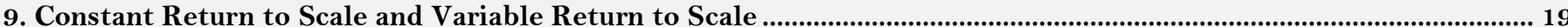

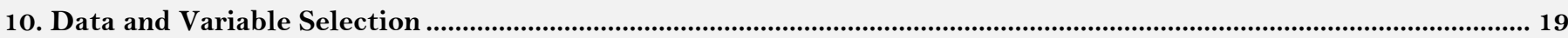

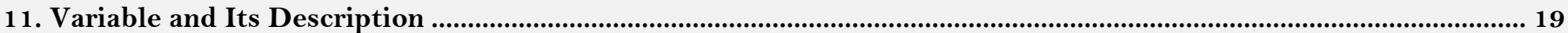

12. Descriptive Analysis of Inputs and Output Variables of Medical Colleges/Universities ............................................ 20

13. The Efficiency and Productivity Estimates of Medical Colleges ...................................................................................... 20

14. Pearson Correlation of Inputs Indicators and Efficiency Scores ....................................................................................... 22

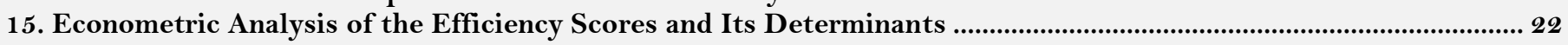

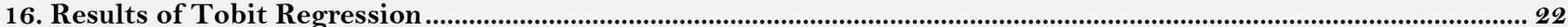

17. Data and Variable Selection for Teaching Hospitals in Punjab ................................................................................... 23

18. Descriptive Analysis of Inputs and Output Variables of Attached Teaching Hospitals.............................................. 23

19. The Efficiency and Productivity Estimates of Teaching Hospitals by Using Output Oriented DEA......................... 24

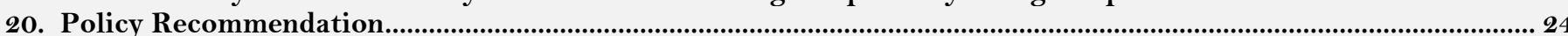

References 
Citation | Asima Ihsan (2017). Measuring the Efficiency of Tertiary Care Hospitals and Medical Colleges in Punjab, an Application of Non- Parametric Approach DEA. Asian Journal of Economics and Empirical Research, 4(1): 14-24. History:

Received: 21 March 2017 Revised: 7 July 2017

Accepted: 13 July 2017

Published: 26 July 2017

Licensed: This work is licensed under a Creative Commons Attribution 3.0 License $($ cc)

Publisher: Asian Online Journal Publishing Group
Funding: This study received no specific financial support.

Competing Interests: The author declares that there are no conflicts of interests regarding the publication of this paper.

Transparency: The author confins that the Transparency: The author confirns that the manuscip accurate, and transparent account of the sital features of the study have been omitted; and that any discrepancies from the study as planned have been explained.

Ethical: This study follows all ethical practices during writing.

\section{Introduction}

Service-oriented commercial world is getting growing apprehension in all over the world. Consequently, the researchers are now more interested to incorporate the efficiency analysis in service sector than to industrial and production sector e.g. the healthcare and education institution. Health sector has been emerged as a fastest growing sector in the global world during last few decades. The health care providing system involves high costs, especially in the developing areas like Punjab because the health service facilities in Punjab are very much resource intensive. So, the efficient utilization of resources required that the healthcare units operates at their full capacity and increase their efficiency to yields best quality healthcare services and more savings. However, unlike other types of service organizations, the management of health sector in Punjab focus more on the supply side of clinical, and non-clinical healthcare physical infrastructure such as to upgrade the infrastructure, building up new primary, secondary and tertiary heath units but the quality issues get less consideration by them. Unfortunately, these clinical and non-clinical considerations are often found to be simple medical error when appraisal of the decisions making is taken. The basic reason is that the policy makers often do not come up with lessons and insights on how to deal with the basic requirement through knowledge based real and applied studies and practices, which is more relevant, useful and sensitive to indigenous people. These inaccuracies in healthcare facilities can be magnificently resolved if hospital management is aware of global better practices. These types of inefficiencies by the management generates the requirement for endorsing access to high-quality healthcare services that is efficient, effective, and equitable the demand for operational research in the health is needs of time and is rising very fast since last few decades. It is for this reason the hospitals and medical colleges efficiencies are regularly evaluated in many developed and developing countries in order to streamline the health activities and to increase control over quantity, quality and efficiency of resources. Many studies have been conducted in this perspective but most of the researchers consider only operational attributes; there are only few studies in literature which have also considered the qualitative indicator such as patient satisfaction level from health service, the data on such indicator is obtained via patient satisfaction surveys quality in healthcare services but however, it is a difficult perspective and not easy job to quantify it.

The global demand for operational research in health care services and succeeding action produced many studies over the years around the world, resulting in extensive literature on healthcare services efficiency measurement. Some of the researchers measure quality and performance of the hospitals which incorporate quality of health care service and efficiency of the practice. Some techniques used by researchers' measures a mixture of quality \& quantity attributes and operational efficiency or they checked the productivity of governmental reforms in healthcare. Thus, the hospitals' efficiency and productivity can be measured by using specific indicators so that the promoted efficiency in health system can be realized, by analyzing and planning for a better efficiency index.

This study intends to make use of non-parametric technique, collectively known as Data Envelopment Analysis (DEA) that is intensively used in measuring the hospital efficiency. The methodological framework of DEA enables the researchers to evaluate the efficiency of those particular organizations which possess multiple homogenous inputs and outputs, and where data about prices is missing. Thus, the technique is well fitted for calculation of hospital efficiency. In reality, multiple inputs/outputs are commonly recurring rationalization for using DEA-type approaches. Furthermore, the decision makers can also use DEA as analytical tool for monitoring purposes such as to point out hospitals with deviating performance structures. Such monitoring may help the management to identify the gaps and increase the efficiency of the hospital. It offers an idealized benchmark to evaluate economic performance of healthcare service. Secondly; the efficiency scores can also be helpful as contextual information in the distribution of resources to different hospitals. This is particularly relevant not only for the regulated tertiary care hospital sectors of Punjab but also for all other health care units in Punjab health system. So, this study incorporates the efficiency measurement of tertiary care hospitals and medical colleges in Punjab.

\section{Public Health Sector in Punjab}

The population of Punjab is more than ten million, which is about 56 percent of the total population of Pakistan. In spite of the fact that the province has an extensive network of primary, secondary and tertiary health care infrastructure, health indicators have not reached the desired level. I77/1000 live births infant mortality ratio, 112/1000 live births Under 5 mortality rate. 300/100,000 live births Maternal mortality ratio (Information \& Communication Cell, 2016) is recorded in year 2015, Total fertility rate has been reached to 4.7 , the malnourished children in Province are about four million, and about a third of all pregnant women are estimated to have iron deficiency anemia. Stunting and wasting is estimated to be 34 percent and 10 percent respectively. Undernourishment is found to be a major contributor to maternal and infant deaths. With these highest mortality ratios, Pakistan slipped from 147th to 149th position in global ranking (Ikram, 2015). Table 1 provides broad indicators of health infrastructure in the state. 
Table-1. Number of Functional and Reporting Health Facilities in Punjab 2015

\begin{tabular}{l|l|l|l|l|l|l|l|l|l}
\hline Health Facility & DHOS & THQ & DHQ & RHC & BHU & MCH & DISP & SHC & TBC \\
\hline Total & 33 & 109 & 27 & 302 & 2483 & 224 & 319 & 26 & 14 \\
\hline Per 100,000 population & 0.032 & 0.106 & 0.026 & 0.296 & 2.43 & 0.219 & 0.312 & 0.254 & 0.013 \\
\hline
\end{tabular}

Besides the above-mentioned health care infrastructure, there is also network of health services that has been specifically designed for implementing various national health programmes. In terms of availability of workforces in health sector, The Punjab has 74500 registered doctors (PM and DC, n.d) of which about 1/7th are working in public health units. Besides doctors, there is qualified manpower such as nurses, technicians, LHVs, LHWs, dispensers, vaccinators, midwives etc., in health sector as well. The total allocated beds allocated to all public health units are 37,272; hospital beds work out to be 37 beds per lakh of population or one bed for 2736 persons.

Health department of Punjab provides preventive, curative and promotive types of care, Preventive health facilities aim to prevent diseases through different interventions, Curative services aims to cure diseases once they befell and Health promotive services are associated to health education. To deliver these services, health units in Punjab are divided into three categories. First, Primary health care contains Rural Health Centers (RHCs), Basic Health Units (BHUs), Dispensaries and Maternal and Child Health Centers (MCHCs). Secondly,

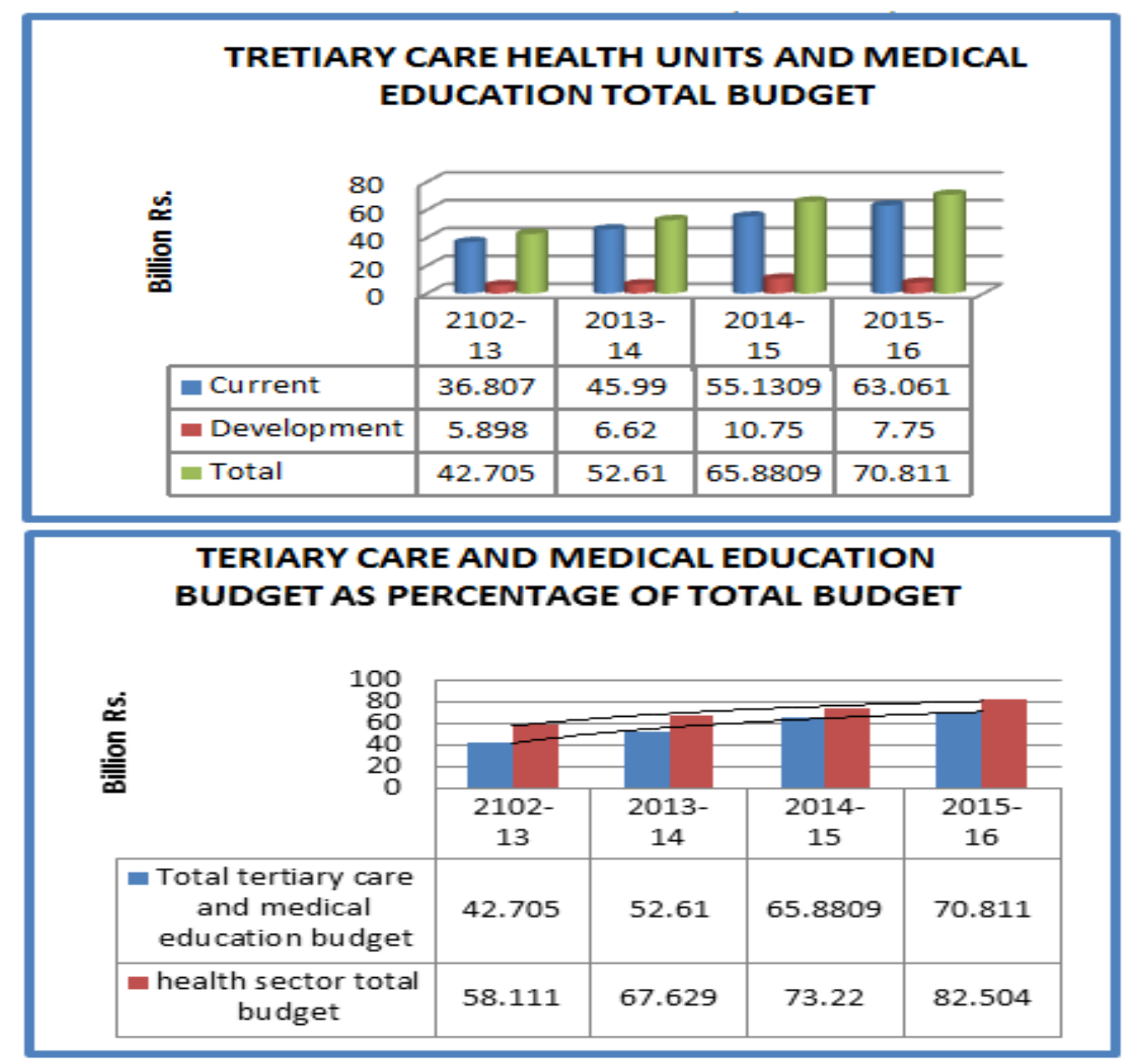

Figure-1. Tertiary Care Hospitals and Medical Education Nominal Budgeting Structure Source: Annual Development Programme (ADP) \& Current Budget statements, Punjab

Secondary health services comprises of Tehsil Headquarter Hospitals (THQs), and District Headquarter Hospitals (DHQs) which are first and second level referral facilities to provide critical, ambulatory and inpatient health care. The third category includes the teaching hospital or Tertiary Care Hospital (TCH) which are the main health units with specialized facilities under the administrative authority of province.

This study made use of tertiary care hospitals and medical colleges' data in private and public sector to measure the capacity utilization of resources of the units fall in third category. Given the declining development budget allocations to the tertiary health sector and generous more focus on preventive health in Punjab has made it critical and very significant the efficient use of existing resources.

Tertiary care health service is the expensive and advance level of health care compared to primary and secondary health care. Curative tertiary care health is the necessity and fundamental right for individuals at micro level, and a crucial requirement for human capital growth and development in a country at the macro level. The total public sector budgetary expenditure on health sector shows positive but not promising figures in last 4 years, however, the share of development spending on tertiary health facilities is still very low (see Figure 1). The total public sector expenditure on health has increased from Rs 58.11billion in 2012-13 to Rs 82.504 billion in 2015-16 but the development budget presents worst picture in year 2015-16 as the share has been reduced to $34 \%$ which was $43 \%$ in $2014-15$.

In case of infrastructure provision, availability of inpatients beds varies across private and public sector, from one bed per 4730 inhabitants in public sector to 9716 in private sector. Both, the number of beds per head of population and the occupancy rate are comparatively high. Admission rates and turnover rates have also been relatively high in provincial tertiary care hospitals. 
Table-2. Population to Bed Ratio in Private and Public Sector Tertiary Care Medical Facilities

\begin{tabular}{l|l|l|l|l}
\hline & Public Sector & Private Sector \\
\hline & Beds & Population to Bed & Beds & Population to Bed Ratio \\
\hline Essential Specialties & 25356 & 8984 & 7248 & 13990 \\
\hline Allied Specialties & 10147 & 9993 & 3188 & 31806 \\
\hline Total & 21434 & 4730 & 10436 & 9716 \\
\hline Overall Public and Private Sectors Population to Bed Ratio & Population to Bed Ratio \\
\hline \multicolumn{7}{l}{} \\
\hline
\end{tabular}

Source: author's calculation by using available data of tertiary heath sector Punjab

\section{Private and Public-Sector Tertiary Care Hospitals in Punjab}

Besides public health and medical institutions, Punjab has a significant existence of private medical colleges and affiliated teaching hospitals. The influence of many of these health units in serving the inhabitants and addressing their health needs is quite impressive. These private sector health and medical institutions have also the managerial capacity to generate their own resources through user fees and donations. The government of Punjab has set some guidelines for these private sector institutions to run which implies that these institutions do not have complete autonomy in their decision making such as in admissions of medical students, recruitment, procurement of supplies and capital investment etc. Most of the decisions are held under the rules of Pakistan Medical and Dental Council (PM\&DC). The improvement in of quality services, efficiency and performance must be the key indicators in these decisions. They generate most of their revenue by the user fees. Another source of revenue can be to raise funds through donations and grants from community and trusts including private sector and industry. This gives them much better financial flexibility. The public sector medical institutions and health units are mostly funded by the public sources. The distribution of medical colleges/attached teaching hospitals in Punjab is given in Table 3.

In Punjab, there are 19 medical colleges and 28 affiliated teaching hospitals in public sector out of which, 6 medical colleges and 8 affiliated hospitals are in Lahore. In private sector, there are 35 medical colleges and 56 attached teaching hospitals. The tertiary care health sector in Punjab is facing breaks and diversion in the accessibility of funds due to more concentration and allocations on the procurement of preventive health care facilities in previous some years as has been shown in Figure 1 that the development budget spent on tertiary care facilities has been decreased by 43 percent to 34 percent in 2015-16. The primary objective to measure efficiency in health sector is to improve the productivity of existed resources of health care (Romley, 2009).

Table-3. Private and Public Medical Colleges and teaching hospitals in Different Districts

\begin{tabular}{l|l|l|l|l}
\hline $\begin{array}{l}\text { District Medical } \\
\text { Colleges/Teaching Hospitals }\end{array}$ & $\begin{array}{l}\text { Public Medical } \\
\text { Institutions }\end{array}$ & $\begin{array}{l}\text { Attached } \\
\text { Tertiary } \\
\text { Hospital }\end{array} \quad$ Care & $\begin{array}{l}\text { private } \\
\text { Institutions }\end{array}$ & $\begin{array}{l}\text { Medical } \\
\text { Tertiary } \\
\text { Hospital }\end{array}$ \\
\hline Lahore & 06 & 08 & 14 & 22 \\
\hline Faisalabad & 01 & 02 & 03 & 04 \\
\hline Sialkot & 01 & 02 & 02 & 05 \\
\hline Multan & 01 & 01 & 03 & 03 \\
\hline Gujarat & 01 & 01 & 01 & 03 \\
\hline Rawalpindi/Islamabad & 03 & 07 & 09 & 14 \\
\hline Sargodha & 01 & 01 & 01 & 02 \\
\hline Sheikhupura & 00 & 00 & 01 & 02 \\
\hline Wah Cantt & 00 & 06 & 0 & 01 \\
\hline $\begin{array}{l}\text { Sahiwal, Gujranwala, Bahawalpur, } \\
\text { Rahim Yar Khan, Dg Khan }\end{array}$ & $05(01$ each) & & 0 \\
\hline Total & 19 & 28 & 35 & \\
\hline Source Paist & & \\
\hline
\end{tabular}

Source: Pakistan Medical \& Dental Council(PM\&DC)

\section{Objective of the Study}

- The primary objective of this study is to evaluate the relative efficiency of public and private tertiary care hospitals and medical colleges of Punjab by using non- parametric approach.

- The second objective is to compare the aggregate efficiency of private sector tertiary health care units to public units.

- To provides suggestion for two sets of institutions on the basis of empirical findings by using data set in specific time period.

\section{Significance of the Study}

Several attempts by various researchers have been made to evaluate the efficiency of public and private sector's hospitals in different countries of the world by using different parametric and non-parametric methods particularly in developing economies like china (Sun, 2016) Saudi Arabia (Al-Shayea, 2011) India (Mogha, 2012) etc., but only few studies have been found in Punjab especial in the area of measuring the efficiency of medical colleges/universities, so this study is an attempt to fill this gap. This study would also provide guidance to the management of each DMU in the institution to make improvement in the use of resources and providing services. This study would highlight the weak aspects of the management of institutions through comparative inputs/outputs analysis and provide proposition to make changes in quantity and quality of inputs and outputs variables in order to achieve high rank of efficiency. 


\section{Organization of the Study}

The rest of the study is ordered as the next part gives a brief view of Data Envelopment Analysis literature and mathematical framework. Part 7-11 discusses the theoretical and mathematical framework of methodology, selected variables and its description, data compilation etc. Part 12-19 talked about the results derived from empirical data. The conclusion with the final comments and future extension has been given in last part.

\section{Theoretical Framework of DEA}

The concepts of efficiency used in this study means the technical efficiency. A Decision-Making Unit (DMU) is considered technically efficient if it is an efficient producer of the product or service relative to others. The classical linear programming provides rationale for Data Envelopment Analysis (DEA) technique. DEA sometimes known as frontier analysis is non-parametric mathematical procedure used to calculate the relative efficiency and productivity of managerial decision making units which possess several inputs and outputs. The DEA has been pioneered by Charnes et al. (1978). The DEA model given by Charnes was known as CCR model. The CCR model was initially applied only on those technologies distinguished by constant return to scale. Some extensions were made in CCR model by Banker et al. (1984) to address the technologies categorized by variable return to scale. Until now, the significant developments in DEA were acknowledged by. At the present time, the usage of DEA methodology to compute the relative efficiency of homogenous decision making units of profit and non-profit organization, for example universities, schools, police stations, public and private libraries, agricultural farms, hospitals, insurance companies, commercial banks, national parks have become very common. The following table gives us information about record of the references published on the use of DEA methodology from 1978 through 2016. This information table supported the growth of DEA as an acknowledged effective tool in a various set of fields.

Table-4. List of the most popular keywords by number or Publication

\begin{tabular}{l|l|l|l}
\hline Keywords & $\begin{array}{l}\text { Number of } \\
\text { Publications }\end{array}$ & Keywords & $\begin{array}{l}\text { Number of } \\
\text { Publication }\end{array}$ \\
\hline Bank or Banking & 4730 & Non-Parametric & 3540 \\
\hline DEA Or Data Envelopment Analysis & 17600 & $\begin{array}{l}\text { Mathematical } \\
\text { Programming }\end{array}$ & 13200 \\
\hline Decision Making Units & Health Care or Hospital & 69 \\
\hline Decision Theory & 29600 & Non-Parametric Statistics & 2620 \\
\hline Economics of DEA & 36800 & Education & 9520 \\
\hline Efficiency & 16300 & Optimization & 4700 \\
\hline Linear Programming & 651000 & Multivariate Analysis & 1680 \\
\hline Management & 17900 & Regression Analysis & 5530 \\
\hline Mathematical Models & 16,100 & Production & 753 \\
\hline Operational Research & 19100 & Benchmarking & 1960 \\
\hline Performance (Management or Evaluation) & 18900 & Resource Utilization & 2700 \\
\hline Productivity & 4890 & Parametric & 80 \\
\hline Technical Efficiency & 22,000 & Statistical Analysis & 58 \\
\hline Source: authors search by using & & \\
\hline
\end{tabular}

Source: authors search by using google scholar search engine

\section{Mathematical Frame Work of DEA}

DEA model in mathematical form can be written as following:

If all decision-making units are expressed by $\mathrm{N}$, every DMU has $\mathrm{m}$ inputs and $\mathrm{n}$ outputs. The technical efficiency score of every DMU can be measured by solving the following model proposed by Charnes et al. (1978)

$$
\begin{aligned}
& \text { for each } \quad{ }^{D M U}{ }_{P} \quad P=1,2,3 \ldots \ldots \ldots . \\
& \text { maximize } \quad E_{P}=\frac{\sum_{j=i}^{n} u_{j}{ }^{y}{ }_{j p}}{\sum_{k=1}^{m} v_{k}{ }^{x} k_{p}} \\
& \text { subject to } \frac{\sum_{j=1}^{n} u_{j}{ }^{y} j_{i}}{\sum_{k=1}^{m}{ }^{m} k^{x} k_{i}} \notin 1 \quad " i \\
& u_{j},{ }^{v}{ }^{3} \mathrm{O} \quad " k,
\end{aligned}
$$

Where

$\mathrm{K}=1,2,3 \ldots \ldots \ldots n$

$\mathrm{J}=1,2,3 \ldots \ldots \ldots . m$

$\mathrm{I}=\mathrm{I}, 2,3 \ldots \ldots \ldots . . . N$

$y_{j i}=$ the amount of output j produced by $i$ th unit,

$x_{k i}=$ the amount of inputs k utilized by $i$ th unit,

$u_{j}=$ weights given to output $j$

$v_{k}=$ weights given to inputs 
The problem set shown in can be transformed into linear programming as following; Decision variables

\section{$u_{j}$ weight of output $j$ (unitless) \\ $v_{k} \quad$ weight of inputsk (unitless)}

The weights are unidentified as priory. The unknown weights of outputs $u_{j}$ and weights of inputs $v_{k}$ are calculated via DEA software, by using the data set of variables, as a method of measuring the relative efficiency of each DMU. These unknown weights are estimated individually for each unit of organization so that the level of highest efficiency score can be attained. Furthermore, these inputs and outputs weights should be categorically positive so that the chance that some inputs or outputs might be omitted in the process of measuring the efficiency of each DMU can be avoided.

\section{Constant Return to Scale and Variable Return to Scale}

The productivity change can be measured under constant return to scale and variable return to scale. The constant return to scale approach was pioneered by Charnes et al. (1978). While the variable returns to scale approach was introduced by Banker et al. (1984). By constant return to scale it means that one unit change in inputs will cause one unit change in output produced while variable return to scale means that each additional unit of input will increase the output more than one unit.

To measure the relative efficiency of wildlife and public and private tertiary care hospitals and medical colleges, DEA has been used in this study. The tertiary care hospitals in urban areas and wildlife parks are considered one of the very important tool of curative health and to generate economic gains for many people around the area of hospital by producing so many activities. Consequently, a competent, adequate, well organized and efficient hospital allows metropolitans to offer healthy human capital and also grows as catalysts for economic, social and ecological development.

\section{Data and Variable Selection}

No computerized and centralized data of medical colleges was available publicly. The data of 35 medical colleges and 54 attached teaching hospitals in both public and private sector for the year 2015 has been collected through survey by the Punjab Economic Research Institute (PERI) team. The variables selected are different from other health sector DMUs (hospitals, BHUs, RHCs) due to change in responsibilities of each. Only those inputs and outputs variable are selected for analysis, which reflect the informative, comprehensive and general results.

For medical colleges, we have considered three outputs such as Total Revenue from student fee, Total Number of Enrolled Undergraduates Student (Salleh et al., 2016) in each medical colleges of Punjab, Total Number of Enrolment of Postgraduate Trainees (Ruggiero, 2016) Quantity Of Undergraduate Degrees ${ }^{1}$ (Johns, 2006). Total number of Medical Teaching Staff (Deng, 2016) is incorporated here as an input variable. Furthermore, medical/lab equipment, fine buildings and essential utilities are all fundamental elements of medical colleges/universities infrastructure that support students, trainees and teaching faculty to perform their work efficiently, accordingly, Total Number Building Infrastructure Facilities ${ }^{2}$ is also included as an indicator of input, Total available Training Beds, Total Employment Related Expenses are also indicators of inputs.

\section{Variable and Its Description}

In medical teaching institutes, many inputs have been used by the management to yield a particular health care outputs through a production process. The eventual goal/output of establishing medical institute in a society is to produce competent professionals in healthcare system to bring the quality change in health status but this indicator is intangible and very hard to measure. Consequently, some intermediary outputs as given in Table 5 customarily become the primary indicators to measure the output. This production process does not occur in a vacuum; besides many internal factors, it is also being influenced by a number of economic, political, social and environmental factors. Both factors are important and equally influence the efficiency of production units. Due to data constraints on external variables, only those indicators are selected for analysis which is considered to be well-regulated by the hospital managers.

The figure illustrates the connection between medical college system inputs, the production process, and the outputs. 


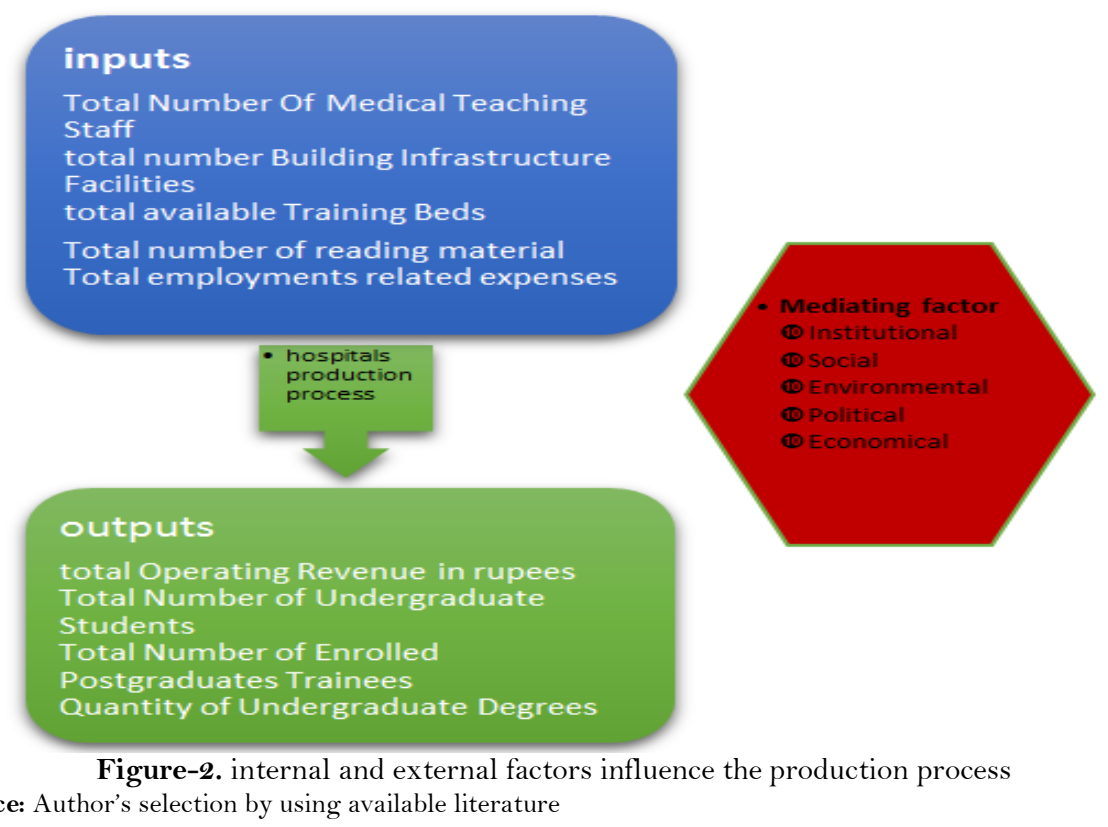

\section{Descriptive Analysis of Inputs and Output Variables of Medical \\ Colleges/Universities}

The wide variation can be observed across medical colleges in private and public sector.by means of the descriptive statistics (mean, slandered deviation, minimum and maximum) (Table 6). The total number of undergraduate students vary between 46 to 1713 . The annual fees from undergraduate students are the major source of revenue in medical colleges which vary from Rs. 1.6 billion to 5.17 billion/year. Similarly, the employment related expenses vary from minimum 2.711 billion to maximum 11.2 billion/year

Table-6. Descriptive Statistics of the Inputs and Outputs of Medical Colleges in Punjab $(\mathrm{N}=35)$

\begin{tabular}{l|l|l|l|l|l}
\hline \multicolumn{1}{c}{ Table-6. Descriptive Statistics of the Inputs and Outputs of Medical Colleges in Punjab $(\mathrm{N}=35)$} \\
\hline Variables & $\mathbf{N}$ & Mean & Std. Dev. & Min & Max \\
\hline Total operational revenue & 35 & 197709778.9 & 176420781.9 & 16608390 & 517484000 \\
\hline Total numbers of undergraduate student & 35 & 726.6857 & 503.1613 & 46 & 1713 \\
\hline Total number of enrolled PG trainees & 35 & 104.257 & 139.0360 & 0 & 447 \\
\hline Quantity of undergraduate degrees awarded & 35 & 125.800 & 123.6275 & 0 & 463 \\
\hline Total number of medical teaching staff & 35 & 206.114 & 126.0672 & 38 & 653 \\
\hline Total number of building infrastructural facilities & 35 & 5.314 & 1.58618 & 5 & 6 \\
\hline Total number of training beds & 35 & 752.886 & 675.9040 & 25 & 3216 \\
\hline Total number reading material in libraries & 35 & 22334.257 & 26014.7935 & 1780 & 94936 \\
\hline Total employment related expenses & 35 & 271182058 & 112411691.2 & 123200100 & 698873640 \\
\hline
\end{tabular}

Source: author's calculation

The output oriented DEA technique has helped us to measure the relative efficiency of 35 private and public sector medical colleges. For given a fixed quantity of inputs, when Decision Making Units (DMUs) are expected to produce output as much as possible, the output oriented model in suitable to apply. The results have been obtained by using DEAP 2.1 software.

\section{The Efficiency and Productivity Estimates of Medical Colleges}

Both the VRS (Variable Return to Scale) and CRS (Constant Return to Scale) has been executed for calculation, because practically, all Decision-Making Units DMus) are not functioning at an optimal scale. Figure 4 provides the relative efficiency estimates 35 public and private medical colleges in Punjab. DEA results have been divided into 3 categories to show the efficiency of medical colleges. these categories are CRS, VRS and Scale Efficiency (SE). The efficiency aggregates in Table 6 shows that $71 \%$ hospitals are technically efficient under CRS and $82 \%$ under VRS. The average VRS efficiency score illustrating that inefficient medical colleges are 10\% less utilized their current resources. The average scale efficiency is $96 \%$ indicating that the existing medical colleges have the capacity of only $4 \%$ to alternate their scale without interrupting their output level. The maximum efficiency score is 100 or 1 whereas, the minimum efficiency score is 0.305 . Seven (20\%) medical colleges are functioning under DRS indicating that their medical education and relating health care services outputs is expected to increase by a lower proportion for any increase in inputs. These medical units are not required to increase their size to achieve optimal level of output or at CRS level. Four DMUs are functioning under IRS and 17 are operating under constant return to scale implying that these DMUs are operation at their optimal level and that increase in inputs will give an equal proportion of output. 


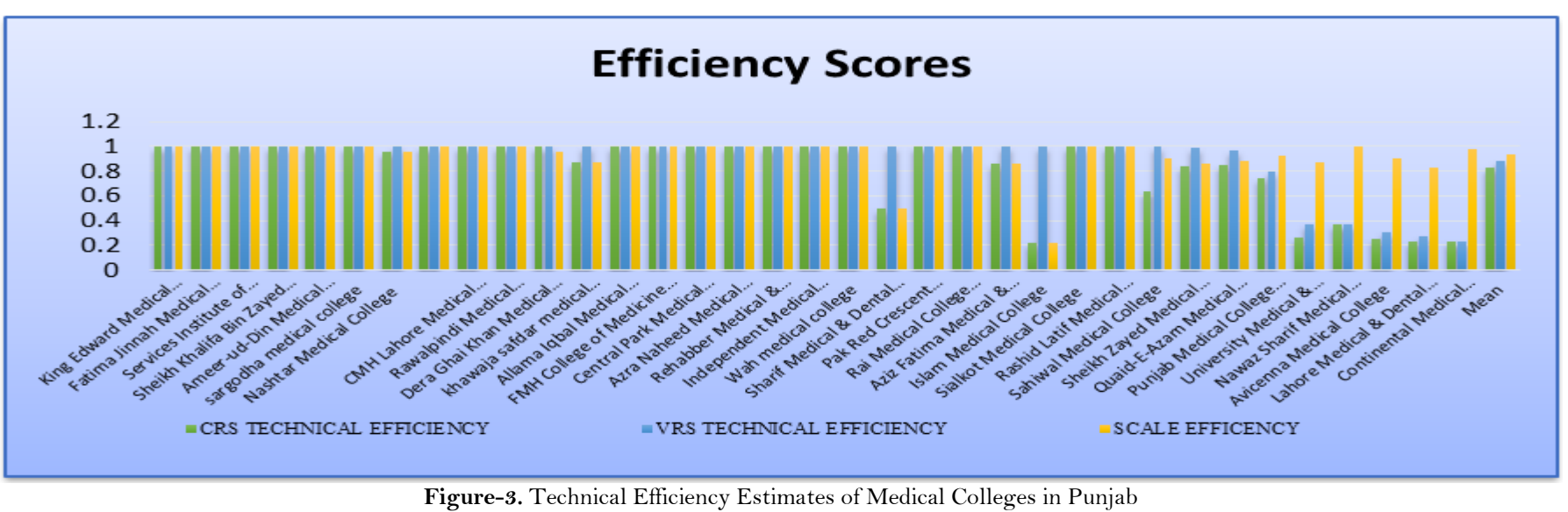

Source: Authors estimations by using DEAP software

Scale inefficiency does not appear to be a common problem in medical colleges of Punjab, $71 \%$ medical colleges are found technically scale efficient. The mean of e scale efficiency score is $93 \%$ which illustrates that on average, the scale inefficient medical colleges can supposedly shrink or increase their size by $7 \%$ without upsetting their current productivity level.

Table-7. Ranking of Medical Colleges on the Base of VRS Technical Efficiency Scores

\begin{tabular}{|c|c|c|c|c|c|}
\hline Medical college name & $\begin{array}{l}\text { RANKI } \\
\text { NG }\end{array}$ & $\begin{array}{l}\text { RETURN TO } \\
\text { SCALE }\end{array}$ & Medical college name & $\begin{array}{l}\text { RANKIN } \\
\text { G }\end{array}$ & $\begin{array}{l}\text { RETURN TO } \\
\text { SCALE }\end{array}$ \\
\hline $\begin{array}{l}\text { King Edward } \\
\text { Lahore }\end{array}$ & 1 & CRS & Wah medical college & 1 & CRS \\
\hline $\begin{array}{llll}\text { Fatima } & \text { Jinnah } & \text { Medical } & \text { University } \\
\text { Lahore } & & & \end{array}$ & 1 & CRS & $\begin{array}{l}\text { Sharif Medical \& Dental } \\
\text { College, Lahore. }\end{array}$ & 1 & IRS \\
\hline Services Institute of Medical Sciences & 1 & CRS & $\begin{array}{lrr}\text { Pak Red } & \text { Crescent } \\
\begin{array}{l}\text { Medical and } \\
\text { College }\end{array} & \text { Dental }\end{array}$ & 1 & CRS \\
\hline $\begin{array}{l}\text { Sheikh Khalifa Bin Zayed Al-Nahyan } \\
\text { Medical and Dental College, Lahore }\end{array}$ & 1 & CRS & $\begin{array}{l}\text { Rai Medical College } \\
\text { Sargodha }\end{array}$ & 1 & CRS \\
\hline Ameer-ud-Din Medical College & 1 & CRS & $\begin{array}{l}\text { Aziz Fatima Medical \& } \\
\text { dental College Fsd }\end{array}$ & 1 & IRS \\
\hline sargodha medical college & 1 & CRS & Islam Medical College & 1 & DRS \\
\hline Nashtar Medical College & 1 & DRS & Sialkot Medical College & 1 & CRS \\
\hline Gujranwala Medical College & 1 & - & $\begin{array}{l}\text { Rashid Latif } \text { Medical } \\
\text { College }\end{array}$ & 1 & CRS \\
\hline $\begin{array}{l}\text { CMH Lahore Medical College and } \\
\text { Institute of Dentistry }\end{array}$ & 1 & - & Sahiwal Medical College & 1 & DRS \\
\hline Rawalpindi Medical College & 1 & DRS & $\begin{array}{l}\text { Sheikh Zayed Medical } \\
\text { College R.Y.k }\end{array}$ & 2 & DRS \\
\hline Dera Ghai Khan Medical College & 1 & IRS & $\begin{array}{l}\text { Quaid-E-Azam Medical } \\
\text { College }\end{array}$ & 3 & DRS \\
\hline khawaja safdar medical college, sialkot & 1 & DRS & $\begin{array}{l}\text { Punjab Medical College } \\
\text { Faisalabad(Allied) }\end{array}$ & 4 & - \\
\hline Allama Iqbal Medical College. & 1 & CRS & $\begin{array}{lr}\text { University } & \text { Medical \& } \\
\text { Dental } & \text { College } \\
\text { Faisalabad } & \end{array}$ & 5 & DRS \\
\hline FMH College of Medicine \& Dentistry & 1 & CRS & $\begin{array}{l}\text { Nawaz Sharif Medical } \\
\text { College } \\
\text { Gujrat }\end{array}$ & 6 & DRS \\
\hline Central Park Medical College & 1 & CRS & $\begin{array}{ll}\text { Avicenna } & \text { Medical } \\
\text { College } & \end{array}$ & 7 & DRS \\
\hline Azra Naheed Medical College & 1 & CRS & $\begin{array}{l}\text { Lahore Medical \& } \\
\text { Dental College }\end{array}$ & 8 & DRS \\
\hline $\begin{array}{l}\text { Rehabber Medical \& Dental College, } \\
\text { Lahore }\end{array}$ & 1 & CRS & $\begin{array}{ll}\text { Continental } & \text { Medical } \\
\text { College Lahore } & \end{array}$ & 9 & IRS \\
\hline Independent Medical College Faisalabad & 1 & CRS & & & \\
\hline
\end{tabular}

Source: Author's calculations

The total number of efficient medical colleges in Punjab are 20 under CRS and 26 under VRS. The 20 colleges are found scale efficient. The maximum efficiency score is $100 \%$ while the minimum efficiency score under CRS is 0.232 obtained by the continental medical college in private sector.

Table-8. Summary of Efficiency Aggregates

\begin{tabular}{l|l|l|l}
\hline EFFICIENCY AGGREGATES & UNDER CRS & UNDER VRS & SCALE EFFICIENCY \\
\hline Number of efficient medical colleges & 20 & 27 & 20 \\
\hline Number of inefficient medical colleges & 15 & 8 & 15 \\
\hline Maximum efficiency (percentage) & 1.00 & 1.00 & 1.00 \\
\hline Minimum efficiency(percentage) & 0.227 & 0.232 & 0.233 \\
\hline
\end{tabular}




\section{Pearson Correlation of Inputs Indicators and Efficiency Scores}

The Pearson Correlation has been computed between input indicators mentioned in Table 4 and VRS efficiency scores. These indicators are not expected to be the defining factors of efficiency scores. These indicators must not be highly correlated to the efficiency scores, because they only partially measure the relation between some inputs and outputs. All the indicators are found insignificantly correlated to efficiency scores (Table 7) except employment related expenses. The employment related expenses however are negatively and significantly correlated with the VRS efficiency scores. The higher the employment related expenses of DMU would resulting a lower efficiency score.

\section{Econometric Analysis of the Efficiency Scores and Its Determinants}

The relative efficiency scores of medical colleges calculated in the previous section was regressed by using Tobit Regression in this section against both discretionary and non- discretionary factors indicated in Figure 2. There are number of regression techniques which can be usefully applied at this second stage to identify the most influencing factors of inefficiency such as the maximum likelihood (ML) based Probit, Logit, the Ordinary Least Square Method(OLS) and Censored \& Truncated Regression (Tobit). In this analysis, we employ the Tobit model or censored normal regression model because of the condition that all values of DEA efficiency scores are clustered around 0 to 1. For computational convenience, the Tobit model is assumed to be left censored to zero. For Tobit regression analysis, the first step is to transform the VRS DEA efficiency scores into inefficiency scores. For transformation, the formula given below is used. (See equation 1)

Inefficiency score $=\frac{1}{\text { VRSefficiencyscore }}-1 \ldots \ldots \ldots . .(1)$

To investigate the relationship between inefficiency of medical colleges and its determining factors, the standard Tobit model can be defined as follows:

$$
\begin{aligned}
& y^{*}=\beta x_{i}+\varepsilon_{i} \\
& y_{i}=y_{i} * \text { ify } *>0 \\
& y_{i}=\text { Ootherwise }
\end{aligned}
$$

where $\varepsilon_{i} \sim N\left(0, \sigma^{2}\right), \beta$ represent the coefficient parameter for all explanatory variable $\mathrm{X} i$. After the transformation of DEA scores, the coefficient of the Tobit model can be interpreted as if it is a coefficient of an ordinary least squares regression that represent the proportionate change

in response variable, due to a one unit change in explanatory variable while keeping constant.

To significantly explain the determinants of inefficiencies, we have selected some potential variables. By using an iterative process, the models consist of several endogenous and exogenous variables have been run but the finally selected model to explain the empirical results is based on chi square and is given below:

Ineffimc $=\alpha+\beta_{1}$ Tenrolled $+\beta_{2} U G \mathrm{deg}+\beta_{3} T R+\beta_{4} \exp +\beta_{5}$ Tstaff $+\beta_{6}$ own

Total undergraduate enrolled students in the institution and undergraduate degrees issued by the institution are the important output of any medical institution. Accordingly, both variables are incorporated here. Student's fees are the major operating revenue of medical college/university. The indicators of total expenditures in term of teaching staff salaries and total number of staff is also incorporated in model. The dummy variable of medical college/university ownership status has also been included in the model to reflect the effect on the inefficiencies

\section{Results of Tobit Regression}

It is observed that the coefficients of all variables are not jointly equal to zero(prob>chi2), so we are in the position to reject the null hypothesis that the regression coefficients of all independent variables are jointly equal to zero, consequently the model as a whole is fit significantly. The coefficient of total number of enrolled undergraduate students reflect negative sign but the coefficient is statistically insignificant at the selected level. Total number of UG enrolled students in the institution are negatively linked to the inefficiencies and is statistically significant to determine the inefficiency. One unit increase in number of UG students is likely to decrease the inefficiency score by $.00205 \%$. Total revenue from student fee(TR) is also found statistically significant which means that this indicator has negatively influencing feature on the inefficiency of medical colleges during the period of analysis. Employment related expenses variable is also found statistically significant and is positively linked to determine the inefficiency of unit. Total teaching staff, available training beds and ownership status are not significant indicators to explain the inefficiency of medical colleges. We can conclude that the management and ownership of medical colleges are likely to be more efficient if focus on the significant indicators influencing the inefficiency of medical colleges. 


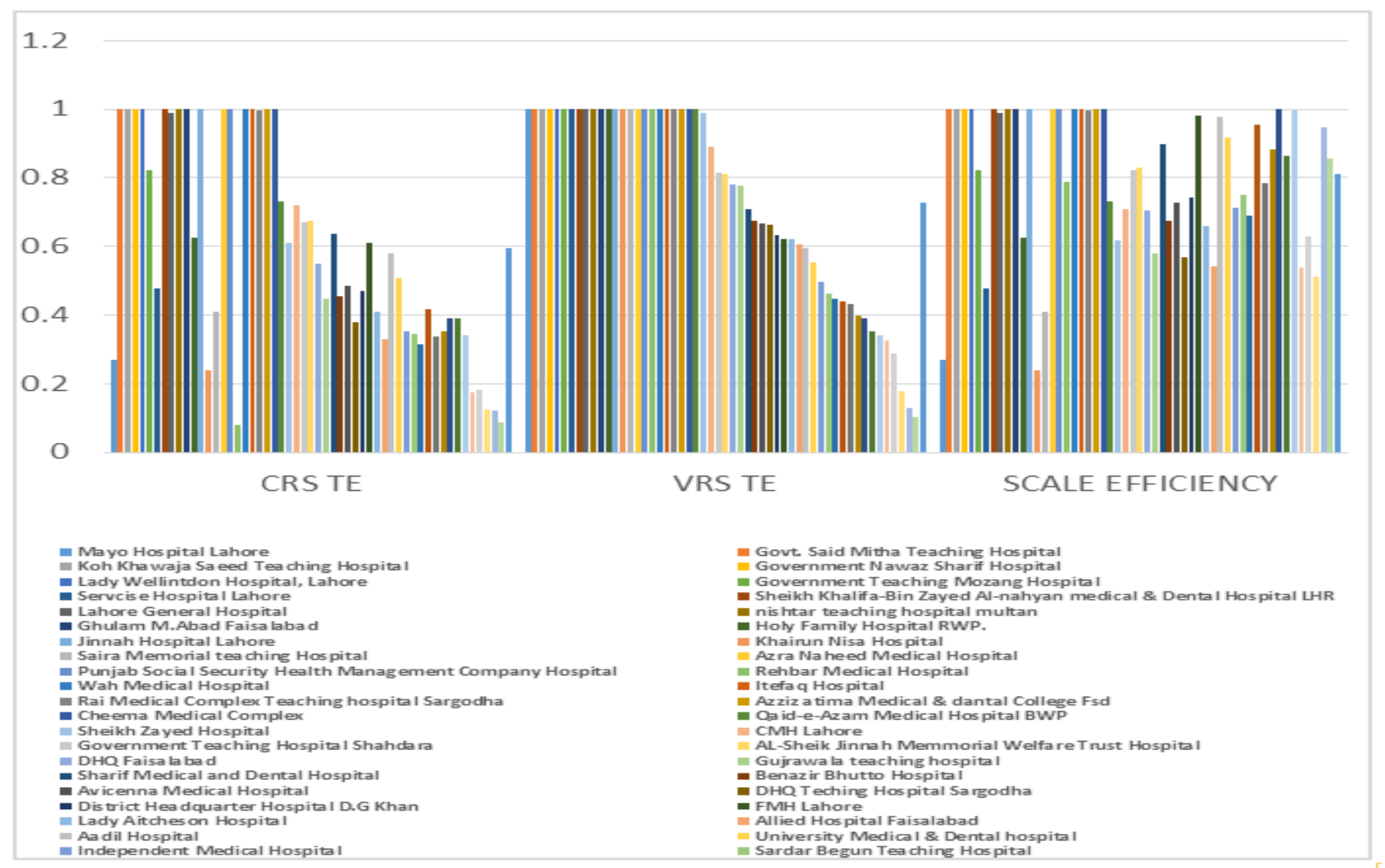

Source: Author's calculations

Figure-4. Efficiency Scores of Teaching Hospitals

Table-10. Results of Tobit model

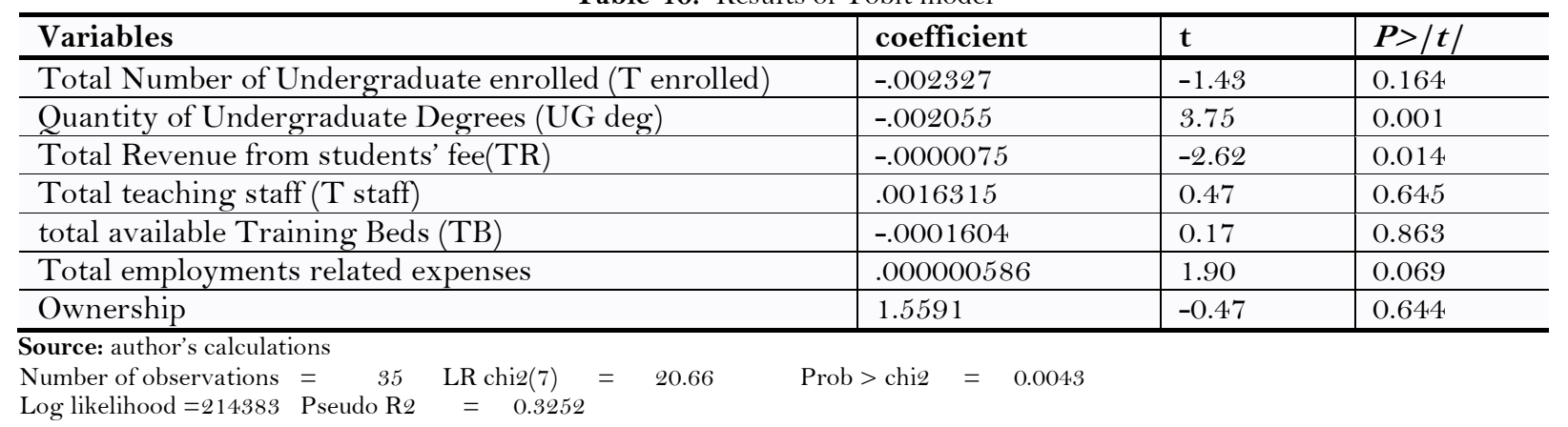

\section{Data and Variable Selection for Teaching Hospitals in Punjab}

The most important output of any hospital is the number of inpatient and outpatient (Mogha, 2012) so both variables are incorporated here for analysis as outputs. Different types of diagnostic test are one of the important source of revenue of teaching hospitals whether they are operated in public or private sector, so used in this study as outputs but are segregated as low, medium and high, on the base of cost per test. Total number of serving staff (Mujasi, 2016) and total beds allocated (Mujasi, 2016) in each hospital are used as inputs

\section{Descriptive Analysis of Inputs and Output Variables of Attached Teaching Hospitals}

Descriptive statistics showed a wide variation across teaching hospitals. The total inpatients vary between 408 to 7080000 . The diagnostic laboratory tests are the major source of revenue in teaching hospitals. Revenue from low cost diagnostic test vary from 40210 to 70200000 . In some teaching hospital, there is no facility of medium and high cost diagnostic test, so minimum values are zero. Similarly, the total allocated beds vary from minimum 25 to maximum 2330.

Table-12. Descriptive Statistics of The Inputs and Outputs of Teaching Hospitals ( $\mathrm{N}=54$ )

\begin{tabular}{l|l|l|l|l|l}
\multicolumn{7}{c}{ Table-12. Descriptive Statistics of The Inputs and Outputs of Teaching Hospitals $(\mathrm{N}=54)$} \\
\hline Variables & $\mathbf{N}$ & Mean & Std. Dev. & Min & Max \\
\hline Total inpatients revenue & 54 & 106701 & 171446.1 & 408 & 7080000 \\
\hline Total outpatients' & 54 & 217088.03 & 176323.5 & 3510 & 734483 \\
\hline Total low diagnostic test & 54 & 15700000 & .000952 & 40210 & 70200000 \\
\hline Total Medium diagnostic test & 54 & 3630000 & .000676 & 0 & 31400000 \\
\hline Total high diagnostic test & 54 & 2320000 & .000425 & 0 & 20400000 \\
\hline Total serving staff & 54 & 433.8333 & 576.5917 & 28 & 3759 \\
\hline Total allocated beds & 54 & 518.5741 & 475.3034 & 25 & 2330 \\
\hline Source: Author's calations by using
\end{tabular}




\section{The Efficiency and Productivity Estimates of Teaching Hospitals by Using Output Oriented DEA}

The relative efficiency estimates of 54 public and private teaching hospitals in Punjab under CRS, VRS and Scale Efficiency (SE) are showed in figure 9. The average efficiency under CRS is about $60 \%$ which indicates that inefficient teaching hospitals are $40 \%$ less utilizing their resources than the optimal level. The resource utilization of teaching hospitals under VRS assumption is $73 \%$ indicating that the inefficient teaching hospitals have $27 \%$ more capacity to better make better utilization of their resources.

\section{Policy Recommendation}

- To make the analysis more definitive, the qualitative and quantitative data on all relevant inputs and output of all private and public sector medical colleges/ teaching hospitals should be frequently composed. Health sector, PM\&DC and UHS can initiate if the data of all type of indicators of medical education/hospitals is available then it can be organized as a part data-collection platforms such as district health information reports and demographic health surveys etc. Furthermore, in order to attract the donor agencies such as the USAID, World Bank, UNICEF for strong funds/aids flowing into the health sector, all types of management weaknesses and resources waste is necessary to be eliminated or significantly reduced. Technical inefficiency is an example of such weaknesses.

- For efficient utilization of resources, the system performance assessment should be a priority area of policy makers.

- For efficient service delivery of medical education and tertiary health care, basic missing staff vacancies must be fulfilled. Staff training to improve the quality of service is also necessary. The government can take initiative to establish a training institute for medical teaching doctors/service providers for capacity building in both private and public sector and to meet the international standers.

- Total number of students enrolled every year and undergraduate degrees issued by the institution are needed to be revised. The inefficiency of medical institutions is likely to be improved by increasing the number of seats.

- majority of the medical teaching institutes/ teaching hospital in both private and public sector are located in Lahore and these are operating at their full capacity level. The government should take initiatives to establish the new tertiary health care institution in other cities also.

- Continuous monitoring and evaluation of the institutions are necessary as in most of the institutions, the serving staff does not meet the PM\&DC criteria. The check list of PM\&DC is also needed to revised according to efficiency estimates.

- Missing specialties in inefficient teaching hospitals are needed to be established to facilitate the inpatients and outpatients.

- There is a great burden of inpatients and outpatients in teaching hospitals at Lahore. The current data shows that the patients are treated beyond the capacity of the Hospitals and Doctors. Government is required to make policies to establish similar facilities in teaching hospitals of other districts as well so as to lower the burden and to provide access to speedy health facilities. The private teaching hospitals may have encouraged in this perspective by enhancing their facilities and infrastructure. The government can provide subsidies to private sector hospitals to improve their services and to provide services at minimum cost.

\section{References}

Al-Shayea, A., 2011. Measuring hospital's units efficiency: A data envelopment analysis approach. International Journal of Engineering \& Technology, 11(6): 7-19. View at Google Scholar

Banker, R.D., A. Charnes and W.W. Cooper, 1984. Some models for estimating technical and scale inefficiencies in data envelopment analysis. Management Science, 30(9): 1078-1092. View at Google Scholar | View at Publisher

Charnes, A., W.W. Cooper and E. Rhodes, 1978. Measuring the efficiency of decision making units. European Journal of Operational Research, 2(6): 429-444. View at Google Scholar | View at Publisher

Deng, S.X., 2016. Data envelopment analysis of the efficiency of the Australian universities: An empirical study. Association for Information Systems AIS Electronic Library (AISeL), Proceedings. Paper No. 206.

Ikram, J., 2015. Pkistan ranking in mother mortality rate fall further. Lahore: Dawn News. Updated May 06, 2015.

Information \& Communication Cell, 2016. Information \& Communication Cell SHC\&ME, Punjab Health Profile, 2016 Health Department Punjab. Retrieved from http://health.punjab.gov.pk/Punjab_Health_Profile.

Johns, J., 2006. Data envelopment analysis and its application to the measurement of efficiency in higher education. Economics of Education Reveiw, 25(3): 273-288. View at Google Scholar | View at Publisher

Mogha, Y., 2012. Performance evaluation of Indian private hospitals using DEA approach. International Journal of Advances in Management and Economics.

Mujasi, E., 2016. How efficient are referral hospitals in Uganda? A data envelopment analysis and tobit regression approach. BMC Health Service Research, 16: 230.

PM and DC, n.d. Statistics. Retrieved from www.pmdc.org.pk: http://www.pmdc.org.pk/Statistics/tabid/103/Default.aspx.

Romley, J.A., 2009. Efficiency and its measurement: What practitioners need to know. American Journal of Managed Care, 15(11): 842-845.

View at Google Scholar
Ruggiero, G.J., 2016. Revenue efficiency in higher education institiutions under imperfect competition. Public Policy and Administration, $\mathrm{O}(\mathrm{O}): 1-14$.

Salleh, M.I., S.N.I.S. Ismail, N. Fadly and N.A.M.L. Habidin, 2016. Efficiency and productivity changes of the Malaysian community colleges. International Journal of Academic Research in Business and Social Sciences, 6(12): 407-424. View at Google Scholar $\mid$ View at Publisher

Sun, Z., 2016. Data envelopment analysis on evaluating the efficiency of public hospitals in Tianjin, China. Transaction of Tianjin University, $22(2): 182-188$. 